\title{
Надія БІЛОУСОВА,
} orcid.org/0000-0003-4167-9649 кандидат педагогічних наук, доиент, доцент кафедри педагогіки, початкової освіти та освітнього менеджменту Ніжинського державного університету імені Миколи Гоголя (Ніжин, Чернігівська область, Украӥна)nv.bilousova@gmail.com

Тетяна ГОРДІЕНКО, orcid.org/0000-0002-4662-1895 кандидат педагогічних наук, доиент, доцент кафедри педагогіки, початкової освіти та освітнього менеджменту Ніжинського державного університету імені Миколи Гоголя (Ніжин, Чернігівська область, Україна) hordienkotana@gmail.com

\section{ДІЯЛЬНІСНИЙ ПІДХІД (НА ПРИКЛАДІ МОДЕЛЮВАННЯ) НА УРОКАХ ЯДС У ПОЧАТКОВІЙ ШКОЛІ}

\begin{abstract}
У статті підкреслюється значення діяльнісного підходу як спрямованих дій на розвиток ключових компетентностей та наскрізних умінь. Характеризується поняття «модель» та аналізується використання методу моделювання як одного з дієвих методів діяльнісного навчання на уроках інтегрованого курсу «Я досліджую світ» у початковій школі. Подаються погляди науковиів на проблему моделювання. Показано трансформацію діяльнісного підходу через розвивальне навчання, поетапного формування розумових дій, формування периептивних дій і проблемного навчання. Наголошується на тому, щз модель є ланцуюгом, який пов'язує почуттєве та раціональне пізнання. Метою моделювання є включення всіх учнів в освітній прочес. Указано, щуо традииійна наочність не може забезпечити необхідний рівень усвідомлення істотних властивостей об' єктів і потребує вдосконалення шляхом упровадження в освітній проиес методу моделювання. Указано, щу новий Державний стандарт початкової загальної освіти трунтується на засадах діяльнісного підходу до навчання. Охарактеризовано етапи прочесу моделювання, як-от постановка й усвідомлення молодшими школярами завдань, власне моделювання, представлення й обговорення моделей; конкретизація $і$ зміна моделі. Визначено, щзо під час роботи з молодшими школярами об'єкти доцільно замімувати знаками або символами. Зазначено, що результатом систематичної роботи в класі є значне покращення здатності дітей до абстрагування відношень між першим і другим (і наступними) станами об'єкта, а також уміння «читати» досить абстрактні записи процесів за допомогою методу піктограм. 3'ясовано причини виникнення труднощів «простого» заміщення та шляхи їх подолання. Доведено, шьо моделювання є важливим комплексним засобом, який спонукає учнів до самооиінки, самовдосконалення, аналізу власних дій, формує логічне мислення, сприяє творчому підходу до прочесу навчання тощо; модель під час навчання виконує функцію планування, організації та контролю.
\end{abstract}

Ключові слова: моделювання, діяльнісний підхід, молодші школярі, ЯДС.

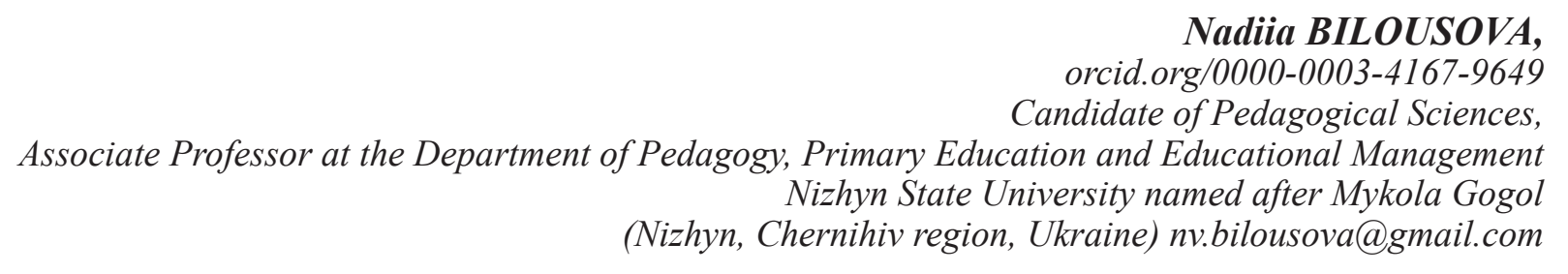

Tetyana HORDIYENKO, orcid.org/0000-0002-4662-1895

Candidate of Pedagogical Sciences,

Associate Professor at the Department of Pedagogy, Primary Education and Educational Management Nizhyn State University named after Mykola Gogol (Nizhyn, Chernihiv region, Ukraine)hordienkotana@gmail.com

\section{ACTIVITY APPROACH (ON THE EXAMPLE OF SIMULATION) IN PRIMARY SCHOOL LESSONS IN PRIMARY SCHOOL}

The article emphasizes the importance of the activity approach as aimed at developing key competencies and cross-cutting skills. The concept of "model" is characterized and the use of the method of "modeling" as one of the effective methods 
of activity learning in the lessons of the integrated course "I explore the world" in primary school is analyzed. The views of scientists on the problem of modeling are presented. The transformation of the activity approach through developmental learning, gradual formation of mental actions, formation of perceptual actions and problem-based learning is shown. The purpose of modeling is to include all students in the educational process. It is stated that traditional clarity cannot provide the necessary level of awareness of the essential properties of objects and needs to be improved by introducing the method of modeling into the educational process. It is indicated that the New State Standard of Primary General Education is based on the principles of the activity approach to education. The stages of the modeling process are characterized: formulation and awareness of tasks by junior schoolchildren, actual modeling, presentation and discussion of models; concretization and change of model. It is determined that when working with younger students, it is advisable to replace objects with signs or symbols. It is noted that the result of systematic work in the classroom is a significant improvement in children's ability to abstract the relationship between the first and second (and subsequent) states of the object, as well as the ability to "read" fairly abstract records of processes using icons. The causes of the difficulties of "simple" substitution and ways to overcome them are clarified. It is proved that modeling is an important complex tool that encourages students to self-assessment, selfimprovement, analysis of their own actions, forms logical thinking, promotes a creative approach to the learning process, etc.; the model during training performs the function of planning, organization and control.

Key words: modeling, activity approach, junior schoolchildren, "I explore the world".

Постановка проблеми. Загальновідомим $є$ факт, що знання засвоюються в діях. Діяльнісний підхід - це спрямованість освітнього процесу на розвиток ключових компетентностей та наскрізних умінь особистості; застосування теоретичних знань на практиці; формування здібностей до самоосвіти й командної роботи; успішна інтеграція в соціумі та професійна самореалізація.

Аналіз останніх досліджень. У науковому світі діяльнісний підхід характеризують через розроблені теорії та концепції:

- розвивального навчання (Д. Б. Ельконін і В. В. Давидов);

- поетапного формування розумових дій (П. Я. Гальперін, Н. Ф. Тализіна);

- формування перцептивних дій (А. В. Запорожець);

- проблемного навчання (психологи Д. М. Богоявленський, Т. В. Кудрявцева; дидакти М. О. Данилов, І. Я. Лернер).

Мета статті - визначити особливості застосування методу моделювання на уроках інтегрованого курсу «ЯДС» у початковій школі.

Виклад основного матеріалу. Моделювання $\epsilon$ одним із методів діяльнісного навчання, засобом активізації пізнавальної діяльності учнів, що 3 давніх часів супроводжує процес навчання.

Простежимо зміст поняття «модель» за словниками. Філософський словник трактує його так: моделювання - спосіб дослідження об'єктів пізнання шляхом вивчення їх моделей. Модель - аналог певного фрагмента природної чи соціальної реальності (в методології науки); виступає в дослідженні як замінник або представник певного фрагмента природної чи соціальної реальності (Шинкарук, 1986). За звичайним словником, модель - це схема якого-небудь фізичного об'єкта чи явища.

У педагогічному словнику зазначено, що модель - це геометричні фігури та тіла, ілюстрації до математичних теорем і формул, які пояснюють і конкретизують абстрактні поняття, математичні закони та аксіоми (Гончаренко, 1997).

Сучасний тлумачний словник української мови так пояснює лексичне значення слова «модель»:

1) зразок, що відтворює, імітує будову і дію певного об' єкта;

2) уявний чи умовний (зображення, опис, схема i т. ін.) образ якогось об'єкта, процесу чи явища, що використовується як його представник.

Моделювати - досліджувати якісь об'єкти, системи, явища, процеси через побудову і вивчення їх моделей (Уйомов, 2006).

Аналіз цих визначень дає змогу зробити висновок, що модель створює мову спілкування, яка, опредметнюючи, матеріалізуючи зміст об'єкта дослідження, дозволяє виявити його найсуттєвіші ознаки. Тобто модель $є$ ланцюгом, який пов'язує почуттєве та раціональне пізнання.

Моделювання тісно пов'язане 3 такими категоріями, як абстракція, аналогія, гіпотеза. Використання моделей у навчанні молодших школярів зумовлене закономірностями освітньої діяльності. Відображення об'єктів називаються моделями; процес їх створення - моделюванням, а використання в науці - модельним дослідженням.

Діти міркують, за словами К. Ушинського, «формами, звуками, фарбами, почуттями». Мислення дитини має наочно-образний характер. Тому таке вагоме значення в навчанні учнів початкових класів має принцип наочності. Ця проблема порушувалася ще Я. А. Коменським, І. Г. Песталоцці, А. Дістервегом, К. Д. Ушинським.

Я. А. Коменський уводить використання наочності в дидактичний принцип побудови навчання на конкретних образах, які безпосередньо сприймаються учнями, а відчуття і сприйняття вважає основною формою пізнання. Він сиверджує: «Якщо нема в наявності речей, то можна замість них використовувати 
копії чи зображення, виготовлені для навчання» (Кузьмінський, 2016).

У наочних поясненнях В. І. Водовозов радить педагогам звертати «увагу учнів на найголовніше, щоб не втомити їх складністю предмета. У цьому значно допомагають пояснювальні моделі, в яких ви або спрощуєте складний предмет, або робите виднішими малопомітні частини» (Кузьмінський, 2016).

Проблему наочності в навчанні з психологічних позицій порушують Л. С. Виготський, В. В. Давидов, А. Н. Леонтьєв, П. Я. Гальперін. Ці вчені стверджують, що в молодшому шкільному віці можливо і важливо формувати теоретичне мислення, але мисленнєвим операціям обов'язково передують предметні дії. Працюючи руками, учні створюють сприятливі умови для всебічного сприйняття різних якостей предметів, a ті чи інші їх комбінації дозволяють дітям знаходити відношення і робити про них висновки.

Тривалий час наочне прирівнювалося до чуттєвого, тому будь-яке засвоєння предмета в чуттєвій формі вважалося наочним. Але не всяка наочність робить навчання наочним. Традиційна наочність не здатна забезпечити необхідний рівень усвідомлення істотних властивостей об'єктів та має бути вдосконалена шляхом упровадження в процес навчання дидактичних моделей, можливості яких ширші.

Л. М. Фрідман описує наочність як засіб моделювання в навчанні. Моделювання вчений розглядає як особливу діяльність із побудови (вибору чи конструювання) моделей. Як будь-яка діяльність, вона має зовнішній практичний зміст і внутрішню психічну сутність. Моделювання як психічна діяльність може бути складником таких психічних процесів, як сприйняття, уявлення, пам'ять, уява i, звичайно, мислення. Ці психічні процеси включаються в моделювання як складну діяльність (Фрідман, 2006).

Моделювання є методом пізнання властивостей предметів через моделі. Це процес створення моделей і дії з ними, які дозволяють досліджувати окремі властивості, сторони предмета, які нас цікавлять. Особливість моделювання (порівняно 3 наочністю) полягає в тому, що предмет вивчається не безпосередньо, а шляхом дослідження іншого об'єкта (аналогічного першому). Між дослідником та об'єктом пізнання наявна модель. Вона не охоплює об'єкт, який вивчається повністю, а виражає тільки деякі сторони, які цікавлять дослідника. Моделювання - це заміна дій зі звичними предметами діями з їх зменшеними зразками, моделями, муляжами, макетами та графічними замінниками (малюнками, кресленнями, схемами).
Просторові моделі розглядаються В.В.Давидовим як узагальнення, яке виникає в діяльності дитини під час планування та контролю. Оволодіння діями просторового моделювання може бути зрозумілим як один із напрямів розвитку символічної (Ж. Піаже) чи знакової (Л. Виготський) функцій свідомості. Дані наукових досліджень доводять перевагу моделювання над традиційною наочністю в процесі переходу дитини від чуттєвої форми знання до понятійного мислення, від конкретного уявлення до поняття (Савченко, 2012).

О. Я. Савченко визначає такі дидактичні функції схематичної наочності: педагогічну підтримку міркувань учнів на етапі первинного сприймання; опору для дітей, які не встигають; використання опори під час самостійної роботи й повторення (Савченко, 2012). В. О. Сухомлинський наголошував: «Образотворчу наочність я розглядаю не тільки як засіб конкретизації уявлень і понять, а i як засіб виходу зі світу уявлень у світ абстрактної думки» (Кузьмінський, 2016).

За ідеями Л. С. Виготського, навчання, відіграючи активну конструктивну роль у процесі дитячого розвитку, саме по собі зовсім не є джерелом цього розвитку. З'єднувальною ланкою між навчанням і розвитком $\epsilon$ власна перетворювальна діяльність дитини. Стратегічною метою розвивального навчання (Д. Б. Ельконіна - В. В. Давидова) $є$ виховання особистості дитини як суб' єкта життєдіяльності. Бути суб'єктом - бути господарем власної діяльності, власного життя: ставити цілі, розв' язувати завдання, відповідати за результати. Досягнення стратегічної мети передбачає дотримання принципів, серед яких:

- принцип дослідження й пошуку (знання не даються дітям у готовому вигляді, вони самі виявляють властивості досліджуваного предмета в процесі розв'язання навчальних завдань);

- принцип моделювання (загальний спосіб діти шукають у предметно-практичній діяльності, центральною навчальною дією якої є моделювання).

Центральний компонент будь-якого уроку організація пізнавальної діяльності учнів. Провідними пізнавальними процесами $є$ мислення й уява. На основі аналітико-синтетичної діяльності за допомогою цих двох процесів відбувається формування знань й інтелектуальних умінь, дослідження проблемних питань і творче розв'язання завдань (Кравчук, 2013). Саме моделювання дає можливість вчителеві «пробудити» дитяче мислення й уяву, активізувати і розвивати пізнавальну активність школярів.

Новий Державний стандарт початкової загальної освіти грунтується на засадах компетентніс- 
ного підходу до навчання, в основу якого покладено ключові компетентності. Важливо, щоб учні не тільки здобули певні знання, а й могли у житті скористатися ними тоді, коли виникне в цьому потреба. За роки навчання вчитель повинен не тільки озброїти учнів деяким багажем знань, а й навчити їх здобувати знання самостійно, сформувати у школярів навчальну діяльність.

Основну мету освіти кардинально перепрограмують зміни, зумовлені масовим входженням у життя людини світової інформаційної мережі. Сучасні засоби комунікації багаторазово збільшили швидкість обміну інформацією і швидкість прийняття рішень.

У сучасному світі майже вся діяльність $е$ колективною, що більше сприяє формуванню компетенцій, ніж індивідуальна діяльність. Тому перед освітянами постала проблема серйозного навчання культурі праці й участі в колективній діяльності, виховання відповідальності за доручену справу та креативного ставлення до виконання завдання.

У сучасних наукових дослідженнях моделювання зі спеціального прийому наукового дослідження перетворилося на важливий метод наукового пізнання і використовується для вивчення окремих сторін об'єкта. Вивчення об'єкта та його властивостей за допомогою моделювання виявляється можливим тому, що будь-яка модель $є$ специфічною формою відображення дійсності.

Моделювання в навчанні (англ. Modelling in education) розуміється, як:

1) спосіб пізнання, яким повинні оволодіти учні;

2) дія - складник навчальної діяльності (Гільберг, 2018).

Повністю погоджуємося з думкою, що «в початкових класах ключові компетентності набувають пріоритетного значення. Математична компетентність передбачає моделювання процесів та ситуацій із застосуванням математичних відношень та вимірювань. Компетентності в галузі природничих наук, техніки і технологій вимагають формування допитливості, прагнення шукати і пропонувати нові ідеї, самостійно чи в групі спостерігати та досліджувати, передбачати і робити висновки на основі проведених досліджень. Навчання впродовж життя передбачає опанування умінь і навичок для подальшого навчання (організацію свого навчального середовища, отримання інформації, iii застосування, визначення власних навчальних цілей та способів їх досягнення, навчання роботі в групі і самостійно)» (Шинкарук, 1986).

На сучасному етапі розвитку освіти результатом навчання $є$ загальна здатність і готовність до діяльності, що грунтується на знаннях і досвіді, набутих у процесі навчання і виховання.

Виділяють такі компоненти навчальної діяльності, як постановка мети, планування роботи, виконання роботи, перевірка результатів, підбиття підсумків, оцінка роботи. Усе це можна сформувати, якщо залучати учнів до активної пізнавальної роботи на уроці, якою і $є$ моделювання. Школярі не пасивно сприймають навчальний матеріал, а «самі здійснюють відкриття» і навчають інших.

Результативне викладання навчального матеріалу варто здійснювати 3 опорою на різні канали сприймання учнями інформації та притаманні їм стилі навчальної діяльності. Відповідно до останніх виокремлюються групи учнів, яким для успішного навчання потрібно:

- спостерігати за групою, бачити чужий досвід, дії і ставлення інших людей;

- навчатися 3 використанням навчальних посібників;

- отримувати досвід, діючи руками, працювати самостійно;

- самостійно використовувати різноманітні засоби для підвищення власної компетентності.

Найбільш результативними щодо засвоєння $\mathrm{i}$ закріплення навчального матеріалу є моделі, створені самими учнями. Процес моделювання можна розділити на кілька етапів:

- постановка й усвідомлення дітьми завдання (учитель ознайомлює школярів зі знаками, символами, які можна використати для побудови моделі);

- власне моделювання (як правило, відбувається у формі групової роботи);

- представлення й обговорення моделей (вибір найзручнішої, найзрозумілішої, виправлення помилок, доповнення тощо);

- конкретизація і зміна моделі.

Від предметної дії учень переходить (через копіювальний малюнок і предметну модель) до графічної моделі (схеми), від неї - до знакової і буквеної (формули), а пізніше - до словесної (правил і визначень).

Другий етап - власне моделювання - кульмінація уроку, «відкриття способу», розв'язання суперечності. Основними методами навчання $€$ дослідження, спостереження, аналіз, порівняння, узагальнення, формулювання висновків. Діти відчувають радість пізнання і досягнення успіху. Як правило, модель - результат групової роботи. Створення моделі вимагає певного часу, щоб більшість дітей усвідомили «відкритий» спосіб. Така організація діяльності ще й дає учням можливість відпрацювати навички спілкування, співпраці. 
На етапі конкретизації і зміни моделі вчитель може запропонувати придумати свої завдання, для виконання яких необхідно звертатися до складеної моделі.

Робота 3 моделлю може бути проведена на будь-якому етапі уроку. Побудували на минулому уроці нову модель. Наступний урок починаєте 3 «озвучування» моделі (читання):

- Пригадайте, що означає ця модель.

- Підберіть слова, що підходять до неї.

- Поясніть тим, кого не було вчора, що означає нова модель.

Якщо графічне подання матеріалу поєднується 3 діяльнісним підходом, то навчання стає значно ефективнішим. Процес моделювання сприяє якісному засвоєнню матеріалу.

Під час роботи 3 молодшими школярами доцільно об'єкти заміщувати знаками або символами. Завжди заміщається не об'єкт, а деяке відношення в об'єкті. На початку першого року навчання від дитини постійно вимагається виконання цієї дії під час опанування різних навчальних предметів. Зокрема, на уроках з ЯДС учитель запитує дітей про те, чи можна якось спростити запис результатів спостережень за погодою, чи обов'язково робити докладні малюнки.

Пропозиції дітей про введення символічних позначень різних станів погоди фіксуються вчителем під кольоровими картинками, що відбивають різні стани погоди, при цьому вчитель послідовно вивішує картинки на дошку. Діти позначають стани погоди символами (сонячно, хмарно, дощ, вітер) поруч із малюнками в зошиті. Таким чином, діти ознайомлюються 3 піктограмами, які в майбутньому стануть основою створення опорних конспектів. Аналогічно вводяться позначення станів інших об'єктів, як-от рідкий і твердий стани води. Учні залюбки працюють творчо, пропонують свої символи для позначення. Найлегше для них позначити стан об'єкта першою буквою слова «ясно» - «Я», «рідкий» - «Р» тощо. Однак такий запис $\epsilon$ незручним, тому що пізніше діти часто не можуть згадати, що вони позначили цією буквою. Те саме відбувається й у випадках, коли для позначення вибирається будь-який інший знак, не пов'язаний за своєю формою $з$ тим, що він позначатиме. Труднощі «простого» символічного заміщення пояснюються, очевидно, тим, що ця дія не $\epsilon$ простою. По-перше, реально завжди заміщується не об'єкт, а деяке відношення в об'єкті. При цьому дитині часто не є зрозумілою природа зв'язку між моделлю і об'єктом, який вона заміщає. Таким чином, можна сказати, що в основі «простого» символічного заміщення лежить роз- горнута складна дія, якщо вона не інтеріоризована, тобто остаточно не привласнена дитиною, що викликає характерні труднощі.

Порівняємо із символічним заміщенням дію функціонального заміщення предмета його ігровим замінником. Не будь-який предмет може заміщати в грі конячку, але паличка може. Через що? Вона дозволяє робити з нею дії, аналогічні діям із реальним предметом, тобто на ній можна скакати, що дитина і робить, відтворюючи відповідні рухи. Завдяки цим рухам паличка може стати символічною заміною коня.

Знаходячи нові способи дій і фіксуючи їх схематично у вигляді загальних способів дій, дитина робить узагальнення у своїх практичних діях.

Уже на першому році навчання більшість дітей можуть побачити за символом невидиме відношення між об'єктами або сторонами реальності.

Так, наприклад, уперше відкривши зміну як процес, як зміну станів об'єкта, діти фіксують відношення попереднього i наступного станів у вигляді стрілки, спрямованої від минулого до майбутнього. Це відбувається тоді, коли діти пробують стати на місце тих, хто не бачив процесу на власні очі. Але стрілка починає «працювати» у той момент, коли нею позначають не зовсім доступні спостереженню процеси, як-от зміна рельєфу місцевості протягом століть або утворення нового виду тварин.

Подібні узагальнення стосуються деякого практичного досвіду дитини, але для молодшого школяра цей досвід виявляється незначним. Важливо підкреслити, що за відсутності спеціального навчання «вузьке охоплення» зберігається в багатьох дітей у середній і старшій школі, що найчастіше призводить до майже нездоланних труднощів у вивченні предметів, які потребують абстрагування.

Результатом систематичної роботи в класі $\epsilon$ значне покращення здатності дітей до абстрагування відношень між першим і другим (і наступними) станами об'єкта, а також уміння «читати» досить абстрактні записи процесів.

Труднощі «простого» заміщення тривають ще багато років, оскільки заміщати необхідно все більш складні об'єкти, що мають свою структуру. Так, наприклад, учні часто не можуть впоратися з визначенням фаз Місяця, використовуючи площинні схеми або рухомі моделі з конструктора, оскільки додатковою операцією в структурі дії заміщення $€$ відтворення об’ємної фігури з плоскої. Педагогічні дії, що дозволяють подолати такі труднощі, складаються у вибудовуванні рядів усе більш віддалених від реальності модельних засобів. Так, визначення 
фаз Місяця може відбутися на моделі з м'ячів і ламп (найбільш наближеної до реальності), на «живих моделях» (замість Сонця і планет рухаються самі діти), на плоских моделях із дитячого конструктора і на схемах, накреслених на папері (найбільш далекий від реальності варіант). Діти (залежно від сили своєї здатності до заміщення) можуть вільно або на прохання вчителя рухатися в будь-якому напрямку на низці цих модельних засобів.

Учні разом з учителем займаються моделюванням загальних способів дій на декількох навчальних предметах. Через розмаїття модельних засобів, що застосовуються для фіксації предметних зв'язків і відносин, діти найчастіше (непомітно для себе) опановують різні мови моделювання. Це нагадує ситуацію багатомовності в дитячому віці, коли дитина від народження спілкується з матір'ю, яка говорить однією мовою, і батьком, котрий говорить іншою. Як у житті маленької дитини настає період, коли вона відчуває певні труднощі, намагаючись розмовляти з батьком про те, про що раніш говорила тільки 3 матір'ю, так і в житті школярів, котрі зіштовхуються із ситуацією, яка вимагає перекладу з однієї модельної мови іншою. Таким чином, навіть до кінця пролонгованої початкової школи ситуація «багатомовності» $є$ характерною під час використання модельних засобів.

Висновки. Отже, для подолання цих феноменів і побудови повноцінної дитячої дії на уроках ЯДС використовуються спеціальні засоби: піктограми, мнемічні схеми, конструювання 3 доступних матеріалів тощо.

\section{СПИСОК ВИКОРИСТАНИХ ДЖЕРЕЛ}

1. Гільберг Т., Тарнавська С., Павич Н. Методика навчання інтегрованого курсу «Я досліджую світ» у 1-2 класах $33 \mathrm{CO}$ на засаді компетентнісного підходу : навч.-метод. посібн. Київ : Генеза, 2018. 256 с.

2. Гончаренко С. Український педагогічний словник. Київ : Либідь, 1997. 375 с.

3. Кравчук Л. Ефективний урок. Початкова школа. Київ : Редакції газет з дошкільної та початкової освіти, 2013. 120 с.

4. Кузьмінський А. І., Омеляненко В. Л. Педагогіка : хрестоматія / Вид. 2-ге, стер. Київ : Знання, 2016.700 с.

5. Савченко О. Я. Дидактика початкової освіти : підручн. Київ : Грамота, 2012. 504 с.

6. Уйомов А. І. Логічні основи методу моделювання. Москва : Просвещение, 2006.

7. Філософський словник; за ред. В. І. Шинкарука. Вид. 2-ге., доп. Київ : УРЕ, 1986. 800 с.

8. Фрідман Л. М. Наочність та моделювання в навчанні. Москва : Знание, 2006. 350 с.

\section{REFERENCES}

1. Hilberg T., Tarnavska S., Pavych N. (2018) Metodyka navchannya intehrovanoho kursu "YA doslidzhuyu svit" u 1-2 klasakh ZZSO na zasadi kompetentnisnoho pidkhodu. Navchal'no-metodychnyy posibnyk. [Methods of teaching the integrated course "I explore the world" in grades 1-2 ZZSO on the basis of the competence approach. Training manual]. Kyiv: Genesis. 256 [in Ukrainian].

2. Goncharenko S. (1997). Ukrayins'kyy pedahohichnyy slovnyk. [Ukrainian pedagogical dictionary]. K .: Lybid. 375 [in Ukrainian].

3. Kravchuk L. (2018). Efektyvnyy urok. [An effective lesson]. Elementary School - K: Newspapers for preschool and primary education. 115. [in Ukrainian].

4. A.I. Kuzminsky, V.L. Omelyanenko. (2016) Pedahohika. [Pedagogy]. K.: Knowledge Press. 700 [in Ukrainian].

5. Didactics of primary education: textbook. Dydaktyka pochatkovoyi osvity. (2012). / Alexandra Yakovlevna Savchenko. $\mathrm{K}$.: Gramota. 504 [in Ukrainian].

6. [Logical bases of modeling method]. (2006). Lohichni osnovy metodu modelyuvannya/AI Uyomov. M .: Enlightenment. [in Ukrainian].

7. [Philosophical Dictionary]. Filosofs'kyy slovnyk. (1986) / Ed. VI Shinkaruk. 2 kind. ext. K .: URE. 800 [in Ukrainian].

8. Friedman L.M. (2006). Naochnist' ta modelyuvannya v navchanni. [Visibility and modeling in teaching]. M .: Znanie. 350 [in Ukrainian]. 